Abstracta Iranica Iranica

Revue bibliographique pour le domaine irano-aryen

Volume 23 | 2002

Comptes rendus des publications de $\mathbf{2 0 0 0}$

\title{
Rebels with a Cause, The Failure of the Left in Iran. London, I. B. Tauris, 1999, 239 p.
}

\section{Christophe Balaÿ}

\section{(2) OpenEdition}

1 Journals

\section{Édition électronique}

URL : http://journals.openedition.org/abstractairanica/35651

DOI : 10.4000/abstractairanica.35651

ISSN : 1961-960X

Éditeur :

CNRS (UMR 7528 Mondes iraniens et indiens), Éditions de l'IFRI

Édition imprimée

Date de publication : 15 mai 2002

ISSN : 0240-8910

Référence électronique

Christophe Balaÿ, « Rebels with a Cause, The Failure of the Left in Iran. London, I. B. Tauris, 1999, 239 p. », Abstracta Iranica [En ligne], Volume 23 | 2002, document 347, mis en ligne le 08 février 2010, consulté le 25 septembre 2020. URL : http://journals.openedition.org/abstractairanica/35651 ; DOI : https:// doi.org/10.4000/abstractairanica.35651

Ce document a été généré automatiquement le 25 septembre 2020.

Tous droits réservés 


\section{Rebels with a Cause, The Failure of the Left in Iran. London, I. B. Tauris, 1999, 239 p.}

\section{Christophe Balaÿ}

1 L'A., professeur assistant à l'Université de San Francisco, brosse la fresque de l'histoire de la gauche iranienne depuis 1953 jusqu'à 1983. Ces trente années décisives pour le destin de l'Iran, sont aussi cruciales et amères pour les partis de la gauche iranienne qui par ses erreurs d'analyse et de choix stratégiques comme de comportement, échoue dans la prise du pouvoir et surtout dans la conscience populaire iranienne. L'A. construit sa réflexion en trois temps historiques : l'effondrement après 1950 et l'appel tiers-mondiste des années 70 (Le parti Tūde) ; la lutte armée et la répression impériale, entre 1970 et 1979 (les Fedā'iyān et les Mojāhedīn) ; les derniers soubresauts et la chute, 1979-1983, (La République islamique). Dans une synthèse finale, l'A. étudie les différents facteurs nationaux et internationaux qui empêchent la gauche de saisir sa chance et qui causent son irrésistible déclin politique à la fin du $20^{\mathrm{e}} \mathrm{s}$.

INDEX

Thèmes : 13.1. Iran 
AUTEURS

CHRISTOPHE BALAŸ

IFRI - Téhéran 